\title{
Matua bromegrass (Bromus catharticus) as a pasture resource for small-scale dairy systems in the highlands of central Mexico
}

\author{
A. Gómez-Miranda ${ }^{1}$, D.A. Plata-Reyes ${ }^{1}$, F. López-González ${ }^{1}$, I.A. \\ Domínguez-Vara $^{2}$, E. Morales-Almaraz ${ }^{2}$, C.M. Arriaga-Jordán ${ }^{1 *}$
}

\begin{abstract}
${ }^{1}$ Instituto de Ciencias Agropecuarias y Rurales (ICAR); ${ }^{2}$ Facultad de Medicina Veterinaria y Zootecnia, Universidad Autónoma del Estado de México (UAEM), Campus El Cerrillo, El Cerrillo Piedras Blancas, C.P. 50090, Toluca, Estado de México, México
\end{abstract}

*Corresponding Author e-mail: cmarriagaj@uaemex.mx

Journal of Livestock Science (ISSN online 2277-6214) 12: 132-140

Received on 27/1/21; Accepted on 24/3/21; Published on 2/4/21

doi. 10.33259/JLivestSci.2021.132-140

\begin{abstract}
The sustainability of small-scale dairy systems in the highlands of Central Mexico is limited by the economic scale due to a high dependence of external inputs, particularly commercial concentrates, as well as the use of low-quality straws that result in high feeding costs which result in low profitability. Grazing of irrigated cultivated pastures based on temperate grasses reduces feeding costs, improves profitability and hence the sustainability of these systems. However, pasture species must be assessed for their adaptation to the agroecological and management conditions of small-scale dairy farms. Therefore, the objective was to evaluate bromegrass (Bromus catharticus Vahl cv Matua) as a pasture resource in comparison with two varieties of perennial ryegrass (Lolium perenne L cv Bargala and cv Payday) and Festulolium (cv Spring Green), in two participatory on-farm experiments in spring and autumn. The first experiment (EXP 1) compared Matua bromegrass (MBRG) with Bargala perennial ryegrass (BPRG), on their own or as a 50:50 mixture of the two grasses. The second experiment (EXP 2) compared Matua bromegrass (MBRG) with Pay Day perennial ryegrass (PDRG) and Festulolium cv Spring green (SGFL). All pastures in both experiments were associated with white clover (Trifolium repens cv Ladino). There were no statistically significant differences found in EXP $1(\mathrm{P}>0.05)$ for animal production variables with a mean milk yield of $19.41 \pm 0.14 \mathrm{~kg} / \mathrm{cow} / \mathrm{day}$. On the other hand the second experiment showed significant differences $(\mathrm{P}<0.05)$ in milk yield for Matua bromegrass $(16.7 \mathrm{~kg}$ cow/day), 9\% less tan for Pay Day perennial ryegrass and Spring Green festulolium. It was concluded that Matua bromegrass showed similar performance to Bargala perennial ryegrass in spring but less than Pay Day perennial ryegrass and Spring Green festulolium in autumn. It is necessary to further investigate if differences were due to a season effect in order to fully establish the value and role of bromegrass as a viable pasture grass species for irrigated pastures in small-scale dairy systems.
\end{abstract}

Keywords: Bromus catharticus; Festulolium; Lolium perenne; feeding strategies; intensive grazing; smallscale dairy entreprise; participatory rural research 


\section{Introduction}

FAO and the Pan-American Dairy Federation recognize small-scale dairy systems as option to reduce poverty (FAO and FEPALE, 2012) identifying the need for improved feeding of herds as means to increase their productivity. Small-scale dairy systems are defined by farms with a small land holding and herds between 3 and 35 cows plus replacements, that rely on family labour for the operation of the farm, and who sell their milk to local buyers and cheese makers (Fadul-Pacheco et al., 2013). In the highlands of central Mexico, small-scale dairy production generates income that enables farming families to overcome poverty (Espinoza-Ortega et al., 2007, Heredia-Nava et al 2017). Grazing of cultivated pastures with limited irrigation has proven a viable feeding strategy (López-González et al., 2017) that reduces feeding costs and increases profitability in these farms (Prospero-Bernal et al., 2017). However, one problem faced by small-scale dairy farmers is the limited irrigation available to their lands in the dry season, which results in reduced herbage growth in pastures (MarínSantana et al., 2020).

Traditionally, cultivated irrigated pastures in the temperate areas of Mexico have been sown to perennial ryegrass (Arriaga-Jordán et al., 2002), as perennial ryegrass (Lolium perenne)is considered and optimal temperate pasture grass with high yields of good quality herbage (Parsons and Chapman, 2000), usually associated with white-clover (Trifolium repens), a legume that increases the nutritive value of herbage and biologically fixes nitrogen improving soil fertility (Beever et al., 2000). However, perennial ryegrass pastures associated with white clover do not tolerate water deficits, reduce growth at temperatures above $25^{\circ} \mathrm{C}$, and are sensitive to overgrazing from high stocking rates (Mayne et al., 2000; Parsons and Chapman, 2000; Ghesquière et al., 2010).

Small-scale dairy systems in the highlands of Mexico only have access to limited irrigation (about every four weeks) and high evapotranspiration during the dry season results in water deficit. These coupled with high stocking rates reduce the persistency of pastures based on perennial ryegrass (Lolium perenne) associated with white clover. Therefore, there is a need to investigate other grass species for pastures that may be better adapted to the difficult agroecological stresses with a prolonged dry season with limited irrigation, and management conditions like high stocking rates of small-scale dairy farmers (Plata-Reyes et al., 2018).

Tall-fescue (Lolium arundinaceum previously Festuca arundinacea) is a temperate grass species more resistant to drought and high temperatures and with results similar to perennial ryegrass in the conditions of small-scale dairy systems (Plata-Reyes et al., 2018; Rosas-Dávila et al., 2020). Also, festulolium varieties, hybrids between perennial or annual ryegrasses (Lolium perenne and L. multiflorum) crossed with fescue species (previously Festuca genus currently also in the Lolium genus) developed to combine the hardiness of the fescues with the nutritional quality of the ryegrasses could be useful in small-scale farms for grazing dairy cows, although some varieties have shown similar results to perennial ryegrass based pastures (López-González et al., 2017; Plata-Reyes et al., 2018).

Another promising grass species is brome or prairie grass (Bromus catharticus). The Matua cultivar was selected in New Zealand to be better adapted to adverse agroecological conditions with higher tolerance to water deficit and high temperatures with comparable yields and nutritive value to perennial ryegrass (Betteridge and Baker, 1983; Belesky et al., 2007). Bromegrass varieties in general, and Matua bromegrass in particular, have not been researched in Mexico for grazing dairy cows.

Therefore, the objective was to assess the performance of dairy cows grazing pastures of Matua bromegrass (Bromus catharticus) compared to pastures of perennial ryegrass (Lolium perenne) of the Bargala (Experiment 1) and Pay Day (Experiment 2) varieties, and Festulolium (Lolium multiflorum x L. perenne $x$ L. pratensis) of the Spring Green variety, all associated with white clover (Trifolium repens cv Ladino) in two different seasons.

\section{Materials and Methods}

Two on-farm experiments were undertaken in two participating small-scale dairy farms following the principles of participatory livestock technology development (Conroy, 2005). Experiment 1 (EXP1) took place in spring-summer (4 June to 15 July) and Experiment 2 (EXP2) in autumn (17 October to 27 November). Each experiment was a 3X3 Latin Square that lasted 42 days divided in three experimental 14-day periods with 10 days for adaptation to diets and 4 days for the collection of samples. Latin Square designs with short experimental periods for grazing dairy cows are well validated in the literature (Pérez-Ramírez et al., 2012; Miguel et al., 2014; Marín-Santana et al., 2020).

\section{Pastures and pasture variables}

In EXP1 a 1.0 ha plot was divided in three equal sub-plots, randomly assigning one of three treatments to each 3,333 $\mathrm{m}^{2}$ subplot where the following grass-white clover treatment pastures were established on 13 March: $\mathrm{MBRG}=$ Matua bromegrass; $\mathrm{BPRG}=$ Bargala perennial ryegrass, and $\mathrm{MBRG}+\mathrm{BPRG}=$ a 50:50 mixture 
of Matua bromegrass and Bargala perennial ryegrass. Sowing rate was $30 \mathrm{~kg}$ grass seed and $3 \mathrm{~kg}$ white clover seed/ha.

In EXP 2 a 1.0 ha plot was also divided in three equal sub-plots randomly assigning the following three grass-clover pasture treatments: PDRG= Pay Day perennial ryegrass; SGFL= Spring Green Festulolium, and MBRG = Matua bromegrass, sown on 30 April at the same rate of $30 \mathrm{~kg}$ grass seed and $3 \mathrm{~kg}$ white clover seed/ha.

Fertilization of all pastures was with $60 \mathrm{~kg} \mathrm{~N}-80 \mathrm{~kg} \mathrm{P}_{2} \mathrm{O}_{5}-60 \mathrm{~kg} \mathrm{~K} / \mathrm{ha}$ at sowing, with urea, diammonium phosphate and potassium chloride as fertilisers, and maintenance fertilizations were with $23 \mathrm{~kg}$ $\mathrm{N} / \mathrm{ha}$ as urea every 28 days. Flood irrigation is provided for all pastures in the farms in the area every four weeks, with the first irrigation in mid-November and the last irrigation in mid-May. Therefore, pastures in EXP1 did not receive any irrigation as the experiment took place during the rainy season, while in EXP2 pastures received two irrigations (one in mid-October and one in mid-November).

Net herbage accumulation (NHA) followed methods described by Hoogendoorn et al. (2016) with three $(0.70 \times 0.70 \times 0.70 \mathrm{~m})$ grazing exclusion cages per pasture treatment, cutting to ground level with shears inside $0.25 \mathrm{~m}^{2}$ quadrats $(0.50 \times 0.50 \mathrm{~m})$ on day 0 outside the cages and day 14 inside the cages. Herbage simples were dried and NHA expressed as $\mathrm{kg}$ DM/ha for each experimental 14-day period.

Recording of compressed sward height $(\mathrm{cm})$ was with a rising plate grass metre at the end of each experimental period, following a zig-zag pattern and taking 20 measurements per pasture treatment plot using mean sward height for analysis (Hodgson, 1991).

Animal management and variables

Three multiparous Holstein cows with similar number of calvings were selected for each experiment. Mean cow live weight for EXP1 was $414 \pm 32 \mathrm{~kg}$, and $505 \pm 54 \mathrm{~kg}$ for EXP2, 90 \pm 75 days in milk for EXP1 and $115 \pm 67$ for EXP2, and mean pre-experimental milk yields of $21.5 \pm 2.86 \mathrm{~kg} / \mathrm{cow} /$ day for EXP1 and $18.9 \pm 3.1$ for EXP2. Milkings were at 5:00/5:30 $\mathrm{h}$ in the morning and 18:00 $\mathrm{h}$ in the evening, by hand (EXP1) and a portable milking machine (EXP2). Cows grazed pastures during daytime between 8 and $9.5 \mathrm{~h} /$ day and kept in a pen overnight with water freely available both in the pastures as in the pens.

As is usual practice in the study area (Plata-Reyes et al., 2018; Marín-Santana et al., 2020) the participating farmers decided to supplement $5 \mathrm{~kg}$ fresh weight of commercial concentrate/cow/day, with a stated crude protein $(\mathrm{CP})$ content of $180 \mathrm{~kg} \mathrm{CP} / \mathrm{kg} \mathrm{DM}$, which was divided in two equal meals given at milking times. The collaborating farmer in EXP1 also decided to provide $2.0 \mathrm{~kg}$ DM/cow/day of fresh cut Kenland red clover (Trifolium pratense) as part of the feeding strategy to his whole herd. This red clover represented $16 \%$ of the diet and was provided in a single meal before the evening milking when cows came from pasture into the overnight pen.

Daily milk yield (kg/cow/day) per cow was recorded during the last four days of each experimental period using mean daily milk yield for the statistical analysis, and milk composition in terms of milkfat, milk protein and lactose with an ultrasonic milk analyser based on the principles described by McClements (1991), and milk urea nitrogen (MUN) determined by the colorimetric method described by Chaney and Marbach (1962).

Chemical composition of herbage

Chemical composition of herbage was from hand-plucked samples simulating grazing collected at the end of each experimental period. Cut red clover in EXP1 was also sampled at the end of experimental periods. Chemical analyses of herbage sample were for dry matter (DM) by drying in a draught oven at $55^{\circ} \mathrm{C}$ till constant weight, ash at $550{ }^{\circ} \mathrm{C}$ in a furnace, crude protein (CP) by the Kjeldahl method (AOAC, 2005), neutral and acid detergent fibre by the micro-bag method (Ankom Technology, 2016). Enzymatic in vitro organic matter digestibility (IVOMD) by the method described by Riveros and Argamentaría (1987). Estimated metabolizable energy (ME) content of herbages was from IVOMD (AFRC, 1993).

Experimental design and statistical analyses

Pasture variables (sward height and NHA) and chemical composition of herbages were analysed with a completely randomized design with three treatments with the model (Kaps and Lamberson, 2004):

$\mathrm{Yi}_{\mathrm{i}}=\mu+T_{i}+e_{i}$.

Where: $\mu=$ General mean, $T_{i}=$ Effect of treatment, $e_{i}=$ Experimental error term.

As mentioned previously, animal variables were analysed as 3 x 3 Latin Square design in each on-farm experiment, where treatment sequences and cow to treatment sequence were randomly assigned with the following model for analyses for animal variables (Kaps and Lamberson, 2004):

$\mathrm{Y}_{\mathrm{jk} l}=\mu+\mathrm{C}_{\mathrm{j}}+\mathrm{P}_{\mathrm{k}}+\mathrm{t}_{\mathrm{l}}+e_{\mathrm{jk} l}$

Where: $\mu=$ General Mean, $C=$ Effect of cow $(j=1,2,3), P=$ Effect of experimental period $(k=1,2,3), t=E f f e c t$ of pasture treatment $(1=1,2,3)$, and $e=$ Experimental error term.

Figures 1, 2, 3, 4, 5 and 6 show the experimental grass species during EXP1 and EXP2 


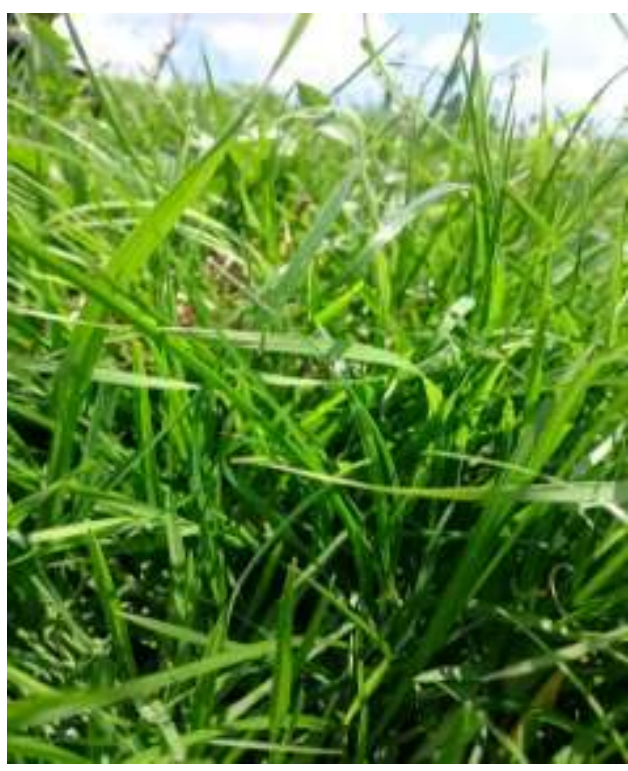

Fig 1 Bargala perennial ryegrass in EXP1

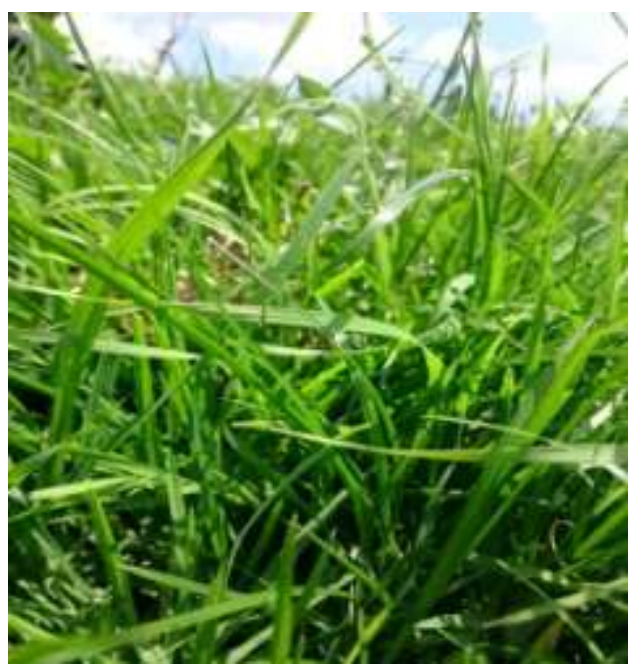

Fig 3 Matua bromegrass in EXP1.

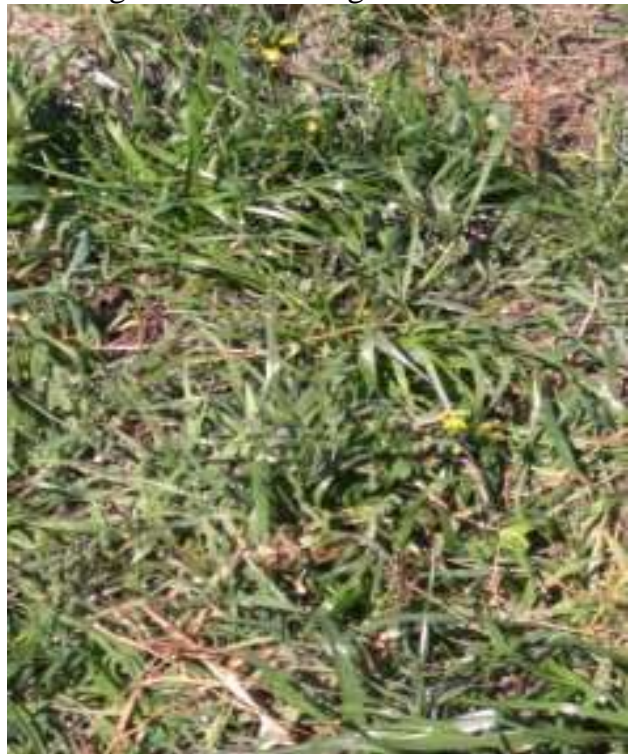

Fig 5 Spring Green festulolium in EXP2

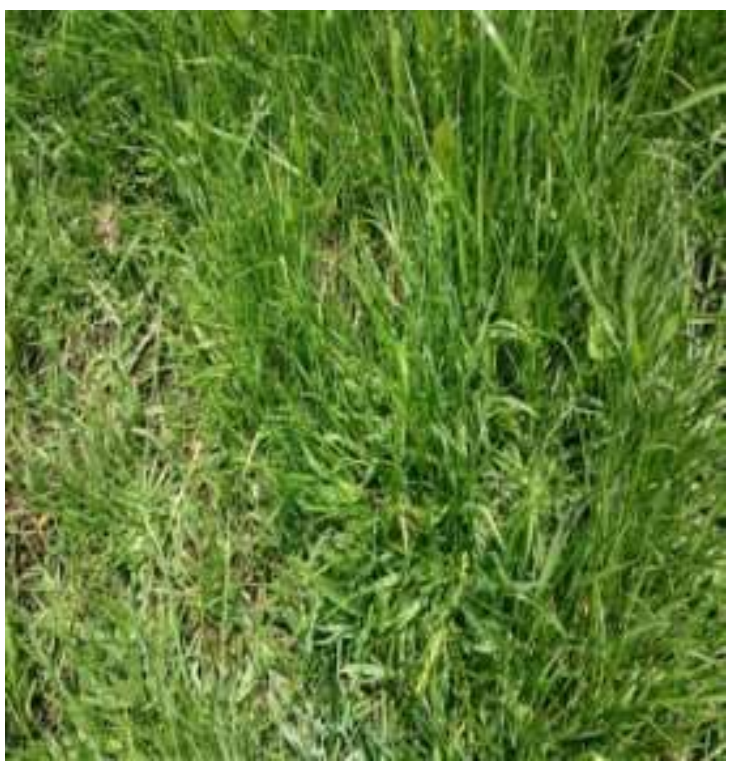

Fig 2 Bargala perennial ryegrass + Matua bromegrass in EXP1

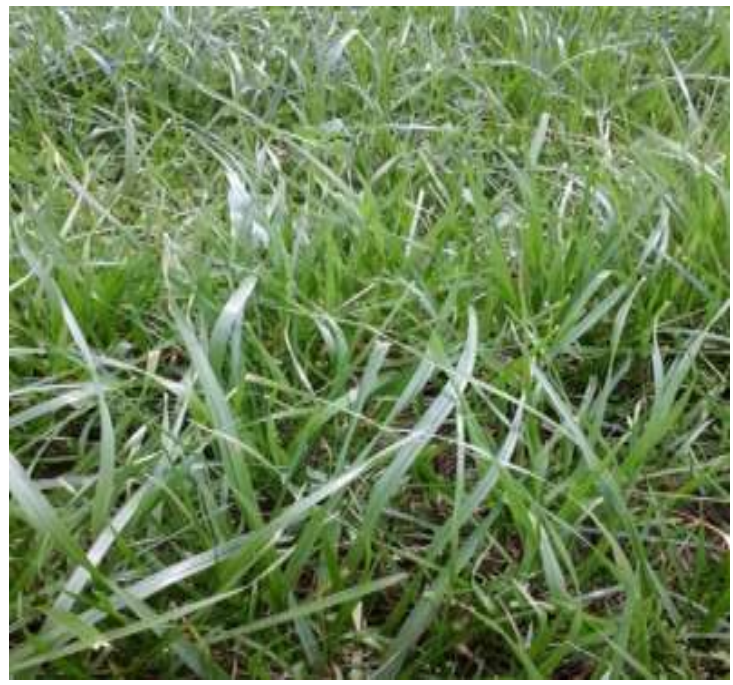

Fig 4 Pay Day perennial ryegrass in EXP2

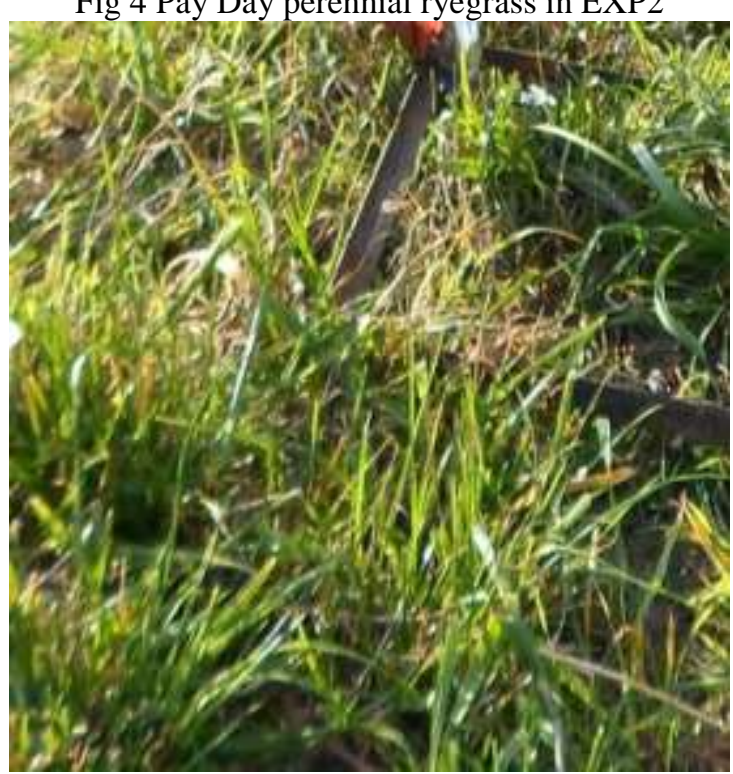

Fig 6 Matua bromegrass in EXP2. 


\section{Results}

Pasture variables and chemical composition of herbages

Table 1 shows results for pasture variables. There were no statistical differences for NHA or sward height $(\mathrm{P}>0.05)$. Mean NHA per period in EXP1 were $308.3 \mathrm{~kg} \mathrm{DM} / \mathrm{ha} / 14$-day period, representing $22.0 \mathrm{~kg}$ $\mathrm{DM} / \mathrm{ha} /$ day. Mean NHA in EXP 2 was $343.9 \mathrm{~kg} \mathrm{DM} / \mathrm{ha} / 14$-day period representing a daily herbage accumulation of $24.6 \mathrm{~kg} \mathrm{DM} / \mathrm{ha} /$ day. Mean grass-metre compressed sward height in EXP1 was $3.5 \mathrm{~cm}$ with no differences $(\mathrm{P}>0.05)$ between the three pasture treatments, and in EXP2 mean sward height was $5.2 \mathrm{~cm}$ also without significant differences $(\mathrm{P}>0.05)$ among pasture treatments.

Table 2 shows results for chemical composition of pasture and the cut red clover herbages. There were no significant differences $(\mathrm{P}>0.05)$ for any of the variables between pasture treatments in both experiments. Herbage quality was good in both experiments. Mean CP content of herbages in EXP1 was $193.4 \mathrm{~g} \mathrm{CP} / \mathrm{kg} \mathrm{DM}$, and $225.2 \mathrm{~g} \mathrm{CP} / \mathrm{kg} \mathrm{DM}$ for EXP2. Acid detergent fibre (ADF) content was $262.3 \mathrm{~g} / \mathrm{kg} \mathrm{DM}$ and $219.6 \mathrm{~g} / \mathrm{kg} \mathrm{DM}$ for EXP1 and ECP2 respectively, with no difference among pasture treatments $(\mathrm{P}>0.05)$ in both experiments.

In contrast, although there were no significant differences $(\mathrm{P}>0.05)$ in NDF contents between pasture treatments in both experiments, mean content of NDF was higher with $572.1 \mathrm{~g} / \mathrm{kg}$ DM in EXP1 compared to $506.7 \mathrm{~g}$ $\mathrm{NDF} / \mathrm{kg} \mathrm{DM}$ in EXP2. There were also no differences between pasture treatments $(\mathrm{P}>0.05)$ in any of the two experiments of IVOMD with a mean of $690.3 \mathrm{~g} / \mathrm{kg}$ DM for EXP1 and $771.9 \mathrm{~g} / \mathrm{kg} \mathrm{DM}$ in EXP2, as there were no differences between pasture treatments of ME content, with a mean of 11.0 MJ ME/kg DM for herbages in EXP1 and 11.3 MJ ME/kg DM in EXP2; indicating a high nutritional value of these pastures.

Cow performance variables

Table 3 shows results for animal variables. There were no differences $(\mathrm{P}>0.05)$ for any animal variable in EXP1 among the MBRG, MBRG+BPRG, and BPRG pasture treatments with a mean milk yield (MY) of 19.4 $\mathrm{kg} / \mathrm{cow} /$ day. However, there were significant differences $(\mathrm{P}<0.05)$ among pasture treatments in EXP2, where cows grazing the Matua bromegrass pasture (MBRG) had a significantly lower milk yield than when grazing the Pay Day perennial ryegrass (PDRG) or the Spring Green festulolium (SGFL) pasture with a mean MY of 18.4 $\mathrm{kg} / \mathrm{cow} /$ day, a $10 \%$ higher milk yield than $16.7 \mathrm{~kg} / \mathrm{cow} /$ day when grazing the MBRG pasture. There were no significant differences among pasture treatments in any of the two experiments for milk composition and milk urea nitrogen $(\mathrm{P}>0.05)$. Live weight figures $(\mathrm{LW})$ are included as indicative of the physical condition of cows since the short duration of experimental periods preclude any further inference. There were no differences $(\mathrm{P}>0.05)$ among pasture treatments in any of the two experiments, with mean live weight of $418 \mathrm{~kg} / \mathrm{cow}$ and 524 $\mathrm{kg} / \mathrm{cow}$ for EXP1 and EXP2.

Table 1. Mean pasture variables.

\begin{tabular}{|c|c|c|c|c|c|c|c|c|c|c|}
\hline \multirow{2}{*}{ Variable } & \multicolumn{3}{|c|}{ EXP1 (Spring) } & \multirow[t]{2}{*}{ SEM } & \multirow{2}{*}{$\begin{array}{l}\mathrm{P}- \\
\text { value }\end{array}$} & \multicolumn{3}{|c|}{ EXP2 (Autumn) } & \multirow{2}{*}{ SEM } & \multirow{2}{*}{$\begin{array}{l}\mathrm{P} \text { - } \\
\text { value }\end{array}$} \\
\hline & MBRG & $\begin{array}{l}\text { MBRG+ } \\
\text { BPRG }\end{array}$ & BPRG & & & PDRG & SGFL & MBRG & & \\
\hline NHA kg DM/ha/period & 317.2 & 282.9 & 324.8 & 111.9 & NS & 382.3 & 222.7 & 426.6 & 80.0 & NS \\
\hline NHA kg DM/ha/day & 22.6 & 20.2 & 20.2 & 7.9 & NS & 27.3 & 15.9 & 30.4 & 5.7 & NS \\
\hline Sward height $(\mathrm{cm})$ & 3.1 & 3.1 & 4.1 & 0.42 & NS & 5.1 & 5.4 & 5.1 & 0.32 & NS \\
\hline
\end{tabular}

NHA= Net herbage accumulation; EXP1: Experiment 1; EXP2: Experiment 2; MBRG: Bromus catharticus Vahl cv. Matua; MBRG+BPRG: Bromus catharticus Vahl cv. Matua + Lolium perenne L. cv. Bargala; BPRG: Lolium perenne L. cv. Bargala; PDRG: Lolium perenne L. cv. Pay Day; SGFL: Festulolium cv. Spring Green; SEM: Standard Error of the Mean;

NS: No significative $(\mathrm{P}>0.05)$; $\mathrm{P}:(\mathrm{P}<0.05)$.

Table 2. Chemical composition of herbages

\begin{tabular}{|c|c|c|c|c|c|c|c|c|c|c|c|c|}
\hline \multirow[t]{2}{*}{ Variable } & \multicolumn{3}{|c|}{ EXP 1 (Spring) } & \multirow[t]{2}{*}{ SEM } & \multirow[b]{2}{*}{\begin{tabular}{|l}
$\mathrm{P}-$ \\
value
\end{tabular}} & \multirow[b]{2}{*}{ RCL } & \multirow[t]{2}{*}{ SEM } & \multicolumn{3}{|c|}{ EXP 2 (Autumn) } & \multirow[t]{2}{*}{ SEM } & \multirow{2}{*}{$\begin{array}{l}\mathrm{P}- \\
\text { value }\end{array}$} \\
\hline & MBRG & $\begin{array}{l}\text { MBRG } \\
+ \text { BPRG }\end{array}$ & BPRG & & & & & PDRG & SGFL & MBRG & & \\
\hline $\mathrm{DM}(\mathrm{g} / \mathrm{kg})$ & 155.5 & \begin{tabular}{|l|}
162.0 \\
\end{tabular} & 156.4 & 10.8 & NS & 190.1 & 3.5 & 175.6 & 192.6 & 246.4 & 39.1 & NS \\
\hline $\mathrm{CP}(\mathrm{g} / \mathrm{kg})$ & 196.0 & 191.7 & 192.6 & 1.9 & NS & 157.5 & 20.6 & 236.1 & 222.4 & 217.3 & 21.1 & NS \\
\hline $\mathrm{OM}(\mathrm{g} / \mathrm{kg})$ & 884.6 & 878.7 & 879.2 & 6.3 & NS & 923.3 & 2.8 & 846.1 & 831.0 & 836.8 & 4.4 & NS \\
\hline NDF $(g / k g)$ & 559.0 & 574.5 & 582.8 & 9.6 & NS & 475.6 & 8.3 & 533.1 & 492.4 & 494.8 & 10.6 & NS \\
\hline $\mathrm{ADF}(\mathrm{g} / \mathrm{kg})$ & 265.7 & 260.1 & 261.3 & 7.6 & $\mathrm{NS}$ & 267.7 & 7.0 & 222.1 & 202.3 & 235.3 & 15.5 & NS \\
\hline IVOMD (g/kg) & 678.4 & 701.6 & 690.9 & 12.2 & $\mathrm{NS}$ & 635.5 & 7.8 & 787.3 & 736.5 & 792.1 & 32.9 & NS \\
\hline $\mathrm{ME}(\mathrm{MJ} \mathrm{kg} / \mathrm{DM})$ & 10.9 & 10.87 & 11.24 & 0.12 & NS & 10.20 & 0.02 & 11.8 & 11.03 & 11.09 & 0.51 & NS \\
\hline
\end{tabular}

DM: dry matter, CP: crude protein, OM: organic matter, NDF: neutral detergent fibre, ADF: acid detergent fibre, IVOMD: in vitro OM digestibility; ME: metabolizable energy, EXP1: Experiment 1; EXP2: Experiment 2; MBRG: Bromus catharticus Vahl cv. Matua;

MBRG+BPRG: Bromus catharticus Vahl cv. Matua + Lolium perenne L. cv. Bargala; BPRG: Lolium perenne L. cv. Bargala; PDRG:

Lolium perenne L. cv. Pay Day; SGFL: Festulolium cv. Spring Green; RCL: Red clover, SEM: Standard Error of the Mean; NS= No significative $(\mathrm{P}>0.05) ; \mathrm{P}=(\mathrm{P}<0.05)$. 
Table 3. Cow performance variables

\begin{tabular}{|l|l|l|l|l|l|l|l|l|l|l|}
\hline \multirow{2}{*}{ Variable } & \multicolumn{3}{|c|}{ EXP 1 (Spring) } & & & \multicolumn{3}{c|}{ EXP 2 (Autumn) } & & \\
\cline { 2 - 12 } & MBRG & $\begin{array}{l}\text { MBRG + } \\
\text { BPRG }\end{array}$ & BPRG & SEM & $\begin{array}{r}P \text { - } \\
\text { valu }\end{array}$ & PDRG & SGFL & MBRG & SEM & $P$-value \\
\hline MY (kg/vaca día) & 19.6 & 19.1 & 19.4 & 0.1 & NS & $18.7^{\mathrm{a}}$ & $18.0^{\mathrm{a}}$ & $16.7^{\mathrm{b}}$ & 0.2 & $*$ \\
\hline LW $(\mathrm{kg})$ & 419 & 418 & 418 & 4.8 & NS & 523 & 528 & 521 & 4.8 & $\mathrm{NS}$ \\
\hline Milk fat $(\mathrm{g} / \mathrm{kg})$ & 30.8 & 30.8 & 30.1 & 0.4 & NS & 38.4 & 36.7 & 39.2 & 0.3 & $\mathrm{NS}$ \\
\hline Protein $(\mathrm{g} / \mathrm{kg})$ & 33.3 & 32.8 & 32.8 & 0.0 & NS & 32.0 & 32.0 & 32.0 & 0.0 & $\mathrm{NS}$ \\
\hline Lactose $(\mathrm{g} / \mathrm{kg})$ & 46.4 & 46.9 & 47.6 & 0.9 & NS & 47.7 & 46.8 & 46.7 & 0.6 & $\mathrm{NS}$ \\
\hline MUN $(\mathrm{mg} / \mathrm{dL})$ & 13.1 & 12.6 & 12.5 & 0.30 & NS & 12.4 & 13.1 & 12.5 & 0.26 & NS \\
\hline
\end{tabular}

MY: Milk yield; LW:Live weight; MUN: Milk Urea Nitrogen; EXP1: Experiment 1 ;EXP2: Experiment 2; MBRG: Bromus catharticus Vahl cv. Matua; MBRGxBPRG: 50:50 mixture of Bromus catharticus Vahl cv. Matua + Lolium perenne L. cv. Bargala; BPRG: Lolium perenne L. cv. Bargala; PDRG: Lolium perenne L. cv. Pay Day; SGFL: Festulolium cv. Spring Green; SEM: Standard Error of the Mean; NS: No significative $(\mathrm{P}>0.05){ }^{\text {ab }}:(\mathrm{P}<0.05)$.

\section{Discussion}

NHA in EXP1 was lower than reports by Celis-Álvarez et al. (2016) form a study in the area with cows grazing Bargala perennial ryegrass/Maximus annual ryegrass pasture associated with white clover, and NHA in EXP2 was lower than reports by Hernández-Ortega et al. (2011) who reported $29 \mathrm{~kg}$ DM/ha/day from grazed ryegrass - white clover pastures. These results are similar to Merino et al. (2019) who reported mean values of herbage availability between 17 and $25 \mathrm{~kg} \mathrm{DM} / \mathrm{cow} /$ day from a study on grazing conditions and management in Chile.

Sward height is an important indicator of both the availability of herbage and of grazing conditions and under continuous grazing optimal height for continuous grazing between 6 and $8 \mathrm{~cm}$, although those figures are measured with a ruler (Mayne et al., 2000), whilst in this experiment it was compressed sward height recorded with a rising plate grass-metre. Sward height indicated more difficult grazing conditions in EXP1 than in EXP2, when higher sward heights were observed. These grass-metre compressed sward heights were higher than reports by Heredia-Nava et al. (2007), who reported $2.4 \mathrm{~cm}$ of compressed sward height. In spite of a mean sward height of $3.4 \mathrm{~cm}$ in EXP1, mean milk yields were $19.4 \mathrm{~kg} / \mathrm{cow} /$ day. In EXP2, although sward height was higher $(5.2 \mathrm{~cm})$, milk yields were lower than in EXP1 (Table 3).

The chemical composition of herbages in both experiments indicate good nutritional quality. This was evident with high crude protein (CP) values of herbages above $190 \mathrm{~g} \mathrm{CP} / \mathrm{kg} \mathrm{DM}$ in EXP1 and above $210 \mathrm{~g} \mathrm{CP} / \mathrm{kg}$ DM in EXP 2. Red clover supplemented in EXP1 also had a high CP content. These CP values were higher than for ryegrass-white clover pastures reported by Heredia-Nava et al. (2007) and Albarrán et al. (2012) who reported $209 \mathrm{~g} \mathrm{CP} / \mathrm{kg} \mathrm{DM}$ and $169 \mathrm{~g} \mathrm{CP} / \mathrm{kg}$ DM respectively. Organic matter (OM) matter content of herbages in both EXP1 and EXP2 were similar to reports from ryegrass-white clover under grazing by Albarrán et al. (2012) who reported $854.4 \mathrm{~g} \mathrm{OM} / \mathrm{kg} \mathrm{DM}$ and Garduño-Castro et al. (2009) who reported $886.5 \mathrm{~g} \mathrm{OM} / \mathrm{kg} \mathrm{DM}$, and Alfonso-Ávila et al. (2012) who reported $870 \mathrm{~g} \mathrm{OM} / \mathrm{kg}$ DM from cut herbage of ryegrass-white clover pastures. Fibre contents are indicatives of herbage and forage quality Neutral detergent fibre (NDF) content of feeds is determinant in the voluntary intake of ruminants. NDF contents of herbages in both EXP1 and EXP2 did not limit voluntary intake, although they were higher than $462 \mathrm{~g} \mathrm{NDF} / \mathrm{kg}$ DM reported by Guadarrama-Estrada et al. (2007) and $499 \mathrm{~g} \mathrm{NDF} / \mathrm{kg}$ DM reported by Hernández-Ortega et al. (2011), similar to $541 \mathrm{~g}$ NDF/kg DM reportaed by Wins et al. (2014), although lower than $576 \mathrm{~g} \mathrm{NDF} / \mathrm{kg}$ DM reported by Albarrán et al. (2012).

Acid detergent fibre (ADF) content of herbages in EXP1 and EXP2 indicated good nutritional quality, with values lower than $282.4 \mathrm{~g}$ ADF/kg DM reported by Heredia-Nava et al. (2007), $290.3 \mathrm{~g}$ ADF/kg DM reported by Guadarrama-Estrada et al. (2007), $369.8 \mathrm{~g} \mathrm{ADF} / \mathrm{kg}$ DM reported by Albarrán et al. (2012), and 319g ADF/kg DM reported by Wims et al. (2014).

Higher contents of ADF in EXP2 may be due to maturity of the cell walls of herbage since this experiment took place in autumn, in agreement with reports by Dodd et al. (2019). Mean in vitro organic matter digestibility (IVOMD) of $690 \mathrm{~g} / \mathrm{kg}$ DM in EXP1 and $772 \mathrm{~g} / \mathrm{kg}$ DM in EXP2 indicated good quality, although these values were lower than reports of $794 \mathrm{~g}$ IVOMD/kg DM by Hernández-Ortega et al. (2011), and $795 \mathrm{~g}$ IVOMD/kg DM reported by Wims et al (2014). Mean IVOMD in EXP1was lower than $718 \mathrm{~g} / \mathrm{kg}$ DM reported by Albarrán-Portillo et al. (2012), but values were higher than that report for EXP2. Estimated metabolizable energy (ME) content of herbages, calculated from IVOMD represented a high ME provision derived from herbages.

Milk yieds in EXP1 and EXP2 are in accordance with Wims et al. (2014) from work in Ireland who reported milk yields of 17.8 and $18.4 \mathrm{~kg}$ milk/cow/day in ryegrass pastures with a high grazing intensity, with sward heights under $4.0 \mathrm{~cm}$ and a herbage mass under 2,000 kg DM/ha. These difficult grazing conditions are similar to those encountered in the experiments herein reported. Mean milk yield in EXP1 was $19.4 \pm 0.14$ $\mathrm{kg} / \mathrm{cow} /$ day which is higher than reports for small-scale dairy systems in the study area. Fadul-Pacheco et al. 
(2013) reported $13.4 \mathrm{~kg} \mathrm{milk/cow/day} \mathrm{and} \mathrm{Prospero-Bernal} \mathrm{et} \mathrm{al.} \mathrm{(2017)} \mathrm{reported} \mathrm{mean} \mathrm{milk} \mathrm{yields} \mathrm{of} 14.5$ $\mathrm{kg} / \mathrm{cow} /$ day, indicating the good quality of the pastures; but similar to milk yields reported by Hernández-Ortega et al. (2011) of $18 \mathrm{~kg} \mathrm{milk/cow/day} \mathrm{and} \mathrm{Albarrán} \mathrm{et} \mathrm{al.} \mathrm{(2012)} \mathrm{who} \mathrm{reported} 19 \mathrm{~kg} / \mathrm{cow} /$ day, although in both those experiments cows were complemented with silage. Mean milk yield in EXP2 was lower than EXP1 at 17.8 $\pm 0.21 \mathrm{~kg} \mathrm{milk} / \mathrm{cow} / \mathrm{day}$, although higher than the above mentioned reports by Fadul-Pacheco et al. (2013) and Prospero-Bernal (2017; and similar to Hernández-Ortega et al. (2011). Milk fat content was lower in EXP1 (30.6 $\mathrm{g} / \mathrm{lg}$ ) than the $35.5 \mathrm{~g} / \mathrm{kg}$ reported by Martínez-García et al. (2015), but mean milk fat content in EXP2 (38.1 g/kg) was higher. Milk fat content in EXP1 was similar, but in EXP2 was higher than the $35.4 \mathrm{~g}$ milk fat $/ \mathrm{kg}$ milk reported by Muir et al. (2014) from research with grazing dairy cows in Australia. Mean protein contents of milk in both experiments were similar to reports by Anaya-Ortega et al. (2009) and Albarrán et al. (2012), although those reports were from grazing cows receiving supplementary silages. Lactose contents were within the established range for raw milk in Mexican standards that specify lactose contents between 43 and $50 \mathrm{~g} / \mathrm{kg}$ milk. There were no significant differences $(\mathrm{P}>0.05)$ in both EXP1 and EXP for milk urea nitrogen (MUN) concentration, and were within normal values (Powell et al., 2011), indicating a balance between nitrogen and energy in the diet.

Conclusion

Results indicate that yield and chemical composition of herbage in all evaluated pastures was of high quality that met an adequate balance of protein and energy nutrition as seen in the milk urea nitrogen values.

Matua bromegrass showed similar results to Bargala perennial ryegrass, on its own or in a 50:50 mix, in EXP1 but had a significant lower animal production in EXP2 than Pay Day perennial ryegrass or Spring Green festulolium. Matua bromegrass is a valuable pasture species in summer but reduces milk yields from grazing cows in autumn for irrigated pastures in small-scale dairy systems.

\section{Acknowledgements}

Authors express gratitude to the farmers who participated in this experiment, whose privacy and that of their families are respected by not disclosing their names. This work was undertaken thanks to funding by the Universidad Autónoma del Estado de México (grant UAEM 3676/2014CIA), and Mexican Consejo Nacional de Ciencia y Tecnología - CONACYT for the postgraduate grants for Aida Gómez-Miranda and Dalia Andrea PlataReyes. Our thanks also to Ms. Maria de Lourdes Maya-Salazar and Ms. Laura Edith Contreras-Martínez for their assistance in laboratory analyses.

Conflict of interest declaration

Authors declare there are no conflicts of interests.

\section{References}

1) AFRC. Animal and Food Research Council, 1993. Energy and protein requirements of ruminants, CAB International, Wallingford, UK.

2) Albarrán B, García A, Espinoza A, Espinosa E, Arriaga CM, 2012. Maize silage in the dry season for grazing dairy cows in small-scale production systems in Mexico Highlands. Indian Journal of Animal Research 46(4): 317-324.

3) Alfonso-Ávila AR, Wattiaux MA, Espinoza-Ortega A, Sánchez-Vera E, Arriaga-Jordán CM, 2012. Local feeding strategies and milk composition in small-scale dairy production systems during the rainy season in the highlands of Mexico. Tropical Animal Health and Production 44: 637-644.

4) Anaya-Ortega JP, Garduño-Castro G, Espinoza-Ortega A, Rojo-Rubio R, Arriaga-Jordán CM, 2009. Silage from maize (Zea mays), annual ryegrass (Lolium multiflorum) or their mixture in the dry season feeding of grazing dairy cows in small-scale campesino dairy production systems in the Highlands of Mexico. Tropical Animal Health and Production 41: 607-616.

5) Ankom Technology, 2016. Procedures (for NDF and ADF). In vitro true digestibility using the DAISY II incubator. http://www.ankom.com; accessed 23 July 2020.

6) AOAC - Association of Official Analytical Chemists, 2005. Official Methods of analysis, 18th Edition. Washington, DC Gaithersburg, MD.

7) Arriaga-Jordán CM, Albarran-Portillo B, García-Martínez A, Castelán-Ortega OA, 2002. On-farm comparison of feeding strategies based on forages for small-scale dairy production systems in the highlands of central Mexico. Experimental Agriculture 38: 375-388.

8) Belesky DP, Rucle JM, Abaye AO, 2007. Seasonal distribution of herbage mass and nutritive value of Prairie grass (Bromus catharticus Vahl). Grass and Forage Science 62: 301-311.

9)Betteridge K, Baker J, 1983. Production from a drought-prone Northland pasture direct drilled with 3 grass cultivars. New Zealand Journal of Experimental Agriculture 11(2): 101-106. 
10) Beever DF, Offer N, Gill M, 2000. The feeding value of grass and grass products. In: Hopkins A. et al.(ed) Grass: Its production and utilization. Chapter 7. 3rd. Edition, British Grassland Society and Blackwell Science, Oxford, UK, pp. 140-195.

11) Celis-Alvarez MD, Lopez-González F, Martínez-García CG, Estrada-Flores JG, Arriaga-Jordán CM, 2016. Oat and ryegrass silage for small-scale dairy systems in the highlands of central Mexico. Tropical Animal Health and Production 48:1129-1134.

12) Chaney AL, Marbach EP, 1962. Modified reagents for determination of urea and ammonia. Clinical Chemistry 8: 130-132.

13) Conroy C, 2005. Participatory Livestock Research. ITDG Publishing, Bourton on Dunsmore, Warwickshire, U.K.

14) Dodd M, Dalley D, Wims C, Elliott D, Griffin A, 2019. A comparison of temperate pasture species mixtures selected to increase dairy cow production and reduce urinary nitrogen excretion. New Zealand Journal of Agricultural Research 62:504-527.

15) Espinoza-Ortega A, Espinosa-Ayala E, Bastida-López J, Castañeda-Martínez T, Arriaga Jordán CM, 2007. Small-scale dairy farming in the highlands of central Mexico: technical, economic and social aspects and their impact on poverty. Experimental Agriculture 43: 241-256.

16) FAO - Food and Agriculture Organization of the United Nations and FEPALE - Pan American Dairy Federation, 2012. Situation of dairying in Latin America and the Caribbean in 2011. FAO Regional Office for Latin America and the Caribbean, Animal Production and Health Division. Santiago, Chile (In Spanish).

17) Fadul-Pacheco L, Wattiaux MA, Espinoza-Ortega A, Sánchez-Vera E, Arriaga-Jordan CM, 2013. Evaluation of sustainability of small-scale dairy production systems in the highlands of Mexico during the rainy season. Agroecology and Sustainable Food Systems 37: 8|82-901.

18) Garduño-Castro Y, Espinoza-Ortega A, González-Esquivel CE, Mateo-Salazar B, Arriaga-Jordán CM, 2009. Intercropped oats (Avena sativa) - common vetch (Vicia sativa) silage in the dry season for small-scale dairy systems in the Highlands of Central Mexico. Tropical Animal Health and Production 41: 827-834.

19) Ghesquière M, Humphreys M, Zwierzykowski Z, 2010. Festulolium, Fodder Crops and Amenity Grasses. Handbook of Plant Breeding 12: 293-316.

20) Guadarrama-Estrada J, Espinoza-Ortega A, González-Esquivel CE, Arriaga-Jordán CM, 2007. Inclusion of maize or oats-vetch silage for grazing dairy cows in small-scale campesino systems in the highlands of central Mexico. Journal of Applied Animal Research 32: 19-23.

21) Heredia-Nava D, Espinoza-Ortega A, González-Esquivel CE, Arriaga-Jordán CM, 2007. Feeding strategies for small-scale dairy systems based on perennial (Lolium perenne) or annual (Lolium multiflorum) ryegrass in the central highlands of Mexico. Tropical Animal Health and Production 39: 179-188.

22) Heredia-Nava D, López-González F., Albarrán-Portillo B. and Arriaga-Jordán C.M. 2017. Supplementation with soya bean meal during the dry season for dairy cows fed on pasture and maize silage in the highlands of Mexico. Journal of Livestock Science (ISSN online 2277-6214) 8: 21-27

23) Hernández-Ortega M, Heredia-Nava D, Espinoza-Ortega A, Sánchez-Vera E, Arriaga-Jordan CM, 2011. Effect of silage from ryegrass intercropped with winter or common vetch for grazing dairy cows in small-scale dairy systems in Mexico. Tropical Animal Health and Production 43: 947-954.

24) Hodgson J, 1991. Grazing Management: Science into Practice. Longman Scientific and Technical, Harlow, UK.

25) Hoogendoorn CJ, Newton PCD, Devantier BP, Rolle BA, Theobald PW, Lloyd-West CM, 2016. Grazing intensity and micro-topographical effects on some nitrogen and carbon pools and fluxes in sheep-grazed hill country in New Zealand. Agriculture, Ecosystems and Environment 217: 22-32.

26) Kaps M, Lamberson W, 2004. Biostatistics for Animal Science. Cromwell Press, Trowbridge, UK.

27) López-González F, Rosas-Davila M, Celis-Alvarez MD, Morales-Almaraz E, Domínguez-Vara IA, ArriagaJordán CM, 2017. Milk production under grazing of different pasture grasses in small-scale dairy systems in the highlands of central Mexico. Journal of Livestock Science 8: 92-97.

28) Marín-Santana MN, López-González F, Hernández-Mendo O, Arriaga-Jordán CM, 2020. Kikuyu pastures associated with tall fescue grazed in Autumn in small-scale dairy systems in the highlands of Mexico. Tropical Animal Health and Production 52, 1919-1926.

29) Martínez-García C, Rayas-Amor A, Anaya-Ortega JP, Martínez-Castañeda FE, Espinoza-Ortega A, Prospero-Bernal F, Arriaga-Jordan CM, 2015. Performance of small-scale dairy farms in the highlands of central Mexico during the dry season under traditional feeding strategies. Tropical Animal Health and Production 47: 331-337.

30) Mayne CS, Wright LA, Fisher GEJ, 2000. Grassland management under grazing and animal response. In: A. Hopkins (Ed), Grass: Its Production and Utilization. Chapter 10, 3rd. Edition, British Grassland Society and Blackwell Science, Oxford, UK, pp. $247-291$. 
31) McClements DJ, 1991. Ultrasonic characterization of emulsions and suspensions. Advances in Colloid and Interface Science 37: 33 -72.

32) Merino V, Jordana Rivero M, Balocchi O, Pulido RG, 2019. Short-term effect of daily herbage allowance restriction on pasture condition and the performance of grazing dairy cows during autumn. Animals 10: 2-17.

33) Miguel MF, Ribeiro-Filho HMN, de Andrade EA, Moraes Genro MT, Delagarde R, 2014. Pasture intake and milk production of dairy cows grazing annual ryegrass with or without corn silage supplementation Animal Production Science 54: 1810-1816.

34) Muir SK, Ward GN, Jacobs JL, 2014. Milk production and composition of mid-lactation cows consuming perennial ryegrass- and chicory-based diets. Journal of Dairy Science 97: 1005-1015.

35) Parsons AJ, Chapman DF, 2000. The principles of pasture growth and utilization. In: Hopkins A. et al.(ed) Grass: Its production and utilization. Chapter 3, 3rd. Edition, British Grassland Society and Blackwell Science, Oxford, UK, pp. 31-89.

36) Pérez-Ramírez E, Peyraud JL, Delagarde R, 2012. N-alkanes v. ytterbium/faecal index as two methods for estimating herbage intake of dairy cows fed on diets differing in the herbage: maize silage ratio and feeding level. Animal 6: 232-244.

37) Plata-Reyes DA, Morales-Almaraz E, Martínez-García CG, Flores-Calvete G, López-González F, ProsperoBernal F, Valdez-Ruiz CL, Zamora-Juárez YG, Arriaga-Jordán CM, 2018. Milk production and fatty acid profile of dairy cows grazing four grass species pastures during the rainy season in small-scale dairy Systems in the highlands of Mexico. Tropical Animal Health and Production 50: 1797-1805

38) Powell JM, Wattiaux MA, Broderick GA, 2011. Short communication: Evaluation of milk urea nitrogen as a management tool to reduce ammonia emissions from dairy farms. Journal of Dairy Science 94: 46904695.

39) Prospero-Bernal F, Martinez-García CG, Olea-Pérez R, López-González F, Arriaga-Jordán CM, 2017. Intensive grazing and maize silage to enhance the sustainability of small-scale dairy systems in the highlands of Mexico. Tropical Animal Health and Production 49: 1537-1544.

40) Riveros E, Argamentería A, 1987. Métodos enzimáticos de predicción de la digestibilidad in vivo de la materia orgánica de forrajes. Avances en Producción Animal 12: 59-75.

41) Rosas-Dávila M, Estrada-Flores JG, López-González F, Arriaga-Jordán CM, 2020. Endophyte-free tall fescue pastures for small-scale dairy systems in the highlands of central Mexico. Indian Journal of Animal Sciences 90: 778-783.

42) Wims CM, Delaby L, Boland TM, O’Donovan M, 2014. Effect of pre-grazing herbage mass on dairy cow performance, grass dry matter production and output from perennial ryegrass (Lolium perenne L.) pastures. Animal 8: 141-151. 